\title{
DETEKSI IgG4 ANTIFILARIA MENGGUNAKAN ANTIGEN REKOMBINAN Bm14 UNTUK DIAGNOSIS FILARIASIS LIMFATIK DI INDONESIA
}

\author{
Devita Febriani Putri ${ }^{1}$ \\ ${ }^{1}$ Departemen Parasitologi, Fakultas Kedokteran, Universitas Malahayati
}

\begin{abstract}
ABSTRAK
Filariasis limfatik adalah penyakit tular vektor yang disebabkan oleh 3 spesies cacing filaria yaitu Wuchereria bancrofti, Brugia malayi, dan Brugia timori. Filariasis ditargetkan untuk dieliminasi pada tahun 2020 oleh WHO. Teknik diagnostik yang digunakan adalah pemeriksaan mikrofilaria pada sediaan darah malam, namun teknik ini memiliki banyak kekurangan, sehingga perlu digunakan metode diagnosis lain, serologi, untuk memantau program eliminasi filariasis.

Deteksi serologi menggunakan Rapid test yaitu diagnosis cepat untuk filariasis limfatik dengan mendeteksi antibodi melalui IgG telah lama digunakan. Namun, deteksi IgG antifilaria mempunyai spesifisitas rendah karena adanya reaksi silang dengan parasit nematoda lain. Akhirnya penggunaan antigen rekombinan $B$. malayi Bm14 dikembangkan, untuk mendeteksi subklas IgG4 antifilaria. Antigen rekombinan filaria $B$. malayi $\mathrm{Bm} 14$ dilaporkan memiliki sensitivitas tinggi untuk mendeteksi $W$. bancrofti, dan B. malayi.

Deteksi antibodi IgG4 antifilaria menggunakan antigen rekombinan Bm 14 merupakan cara diagnosis yang tepat untuk filarisis. Hasil penelitian melaporkan bahwa antigen rekombinan Bm14 lebih sensitif dan spesifik dalam mendeteksi filariasis bankrofti dan filariasis Brugia, dibandingkan dengan antigen rekombinan yang lain yaitu WbSXP dan BmR1. Penelitian lain melaporkan bahwa pengukuran level antibodi IgG4 yang meningkat secara signifikan pada infeksi aktif dan penurunan level antibodi IgG4 tersebut setelah pengobatan massal. Selain itu IgG4 antifilaria juga dapat terdeteksi pada individu yang negatif mikrofilaria maupun antigen. Bm 14 merupakan rekombinan antigen yang memiliki sensitifitas dan spesifisitas yang baik dalam mendeteksi filariasis bankrofti dan filariasis brugia, sehingga dapat lebih efektif dan diandalkan di Indonesia.
\end{abstract}

Kata Kunci: Filariasis limfatik; antigen rekombinan; Bm14; IgG4

\section{PENDAHULUAN}

Filariasis limfatik merupakan

penyakit tular vektor yang disebabkan

oleh tiga spesies cacing nematoda jaringan yaitu Wuchereria bancrofti, Brugia malayi, dan Brugia timori. Penyakit ini memberikan resiko infeksi lebih dari semiliyar orang pada 80 negara di dunia termasuk Indonesia (Scott, 2000). Sehingga filariasis limfatik menjadi salah satu penyakit yang ditargetkan untuk dieliminasi pada tahun 2020 oleh Organisasi Kesehatan Dunia (WHO) (Ottesen, 2000).

Perhitungan mikrofilaria pada pemeriksaan mikroskopik merupakan diagnosis gold standar untuk filariasis. Tetapi metode ini kurang efektif, karena kesulitannya mengambil sampel darah pada malam hari, dan sensitivitas yang tidak adekuat, serta kurang sensitif pada pasien Tropical Pulmonary 
Eosinophilic dan elephantiasis (Haarbrink et.al, 1995). Akhirnya dikembangkan metode diagnosis yang lebih efektif yaitu dengan deteksi adanya antigen filaria maupun antibodi terhadap filaria pada seseorang.

Hingga saat ini pemeriksaan antigen untuk filariasis hanya dapat dilakukan untuk filariasis bankrofti. Dikarenakan belum diketahui antigen yang tepat untuk pemeriksaan infeksi brugia, deteksi antibodi (IgG4 anti filaria) merupakan alternatif terbaik untuk pemeriksaan filariasis brugia. Selain itu deteksi anti filarial IgG4 memiliki korelasi yang kuat terhadap infeksi yang aktif, dan lamanya infeksi Haarbrink et al., 1995). Namun deteksi antibodi dengan menggunakan antigen dari ekstrak filaria utuh memiliki reaksi silang terhadap antigen nematoda lain, maka dikembangkan penggunaan antigen rekombinan (Lamie et al., 2004).

Antigen rekombinan $\mathrm{Bm} 14$ telah dikembangkan oleh WHO, karena memiliki sensitivitas yang tinggi dalam mendeteksi antifilaria IgG4 pada penderita filarisis baik yang terinfeksi oleh spesies W. bancrofti, B. malayi, ataupun B. timori (Lamie et al., 2004 dan Weil et al., 1999). Dengan mempertimbangkan sensitifitas dan spesifisitasnya dan dengan melihat distribusi spesies penyebab filariasis di Indonesia, maka deteksi IgG4 antifilaria menggunakan antigen rekombinan $\mathrm{Bm}$
14 untuk menentukan daerah bebas filariasis di Indonesia yang dipantau secara serologi sesuai dengan pedoman WHO akan lebih efektif dan tepat guna.

\section{FILARIASIS LIMFATIK DI INDONESIA}

Terdapat 3 spesies cacing filaria yang diketahui endemik di Indonesia. Ketiga parasit ini terdistribusi secara luas ke seluruh kepulauan Indonesia dan menyebabkan 5 perbedaan tipe ekologi dari limfatik filariasis yang dapat diidentifikasikan:

1. Wuchereria bancrofti Urban, endemic di Jakarta dan sekitarnya ditransmisikan oleh nyamuk Culex quinquefasciatus.

2. Wuchereria bancrofti Rural, endemik tinggi di Irian Jaya, dapat ditranmisikan oleh nyamuk vektor Anopeles farauti dan Anopheles punctulatus

3. Brugia malayi antropophilic periodik nokturnal, endemik di Sulawesi dan ditransmisikan oleh Anopheles barbirostris.

4. Brugia malayi antropo-zoophilic dengan periodisitas yang bervariasi dan dapat ditransmisikan oleh berbagai vektor dari spesies nyamuk Mansonia.

5. Brugia timori, yang diidentifikasikan sebagai spesies baru pada tahun 1966 oleh peneliti Indonesia, hanya ditemukan di Timor Timur dan Maluku bagian selatan. Spesies ini ditranmisikan oleh vektor Anopheles barbirostris (Terhell, 2002). 


\section{PEMERIKSAAN} FILARIASIS

\author{
Pemeriksaan antibodi dapat \\ dilakukan dengan metode ELISA \\ (Enzyme Linked Immunosorbent Assay) \\ atau Rapid Test (Gambar 1). Dengan \\ pemeriksaan ini darah dapat diambil \\ siang atau malam hari.
}

Diagnosis untuk filariasis limfatik dengan mendeteksi antibodi melalui IgG telah lama dikembangkan. Namun, deteksi IgG anti-filaria mempunyai spesifisitas rendah karena adanya reaksi silang dengan parasit nematoda lain. Kemudian dilaporkan bahwa sensitivitas dan spesifisitas dapat ditingkatkan dengan deteksi subklas IgG4. Deteksi antibodi IgG4 anti-filaria ini didasarkan pada peningkatan secara signifikan level antibodi IgG4 pada infeksi aktif dan penurunan level antibodi IgG4 tersebut setelah pengobatan (Terhell, 2002 dan Tisch et al, 2008).

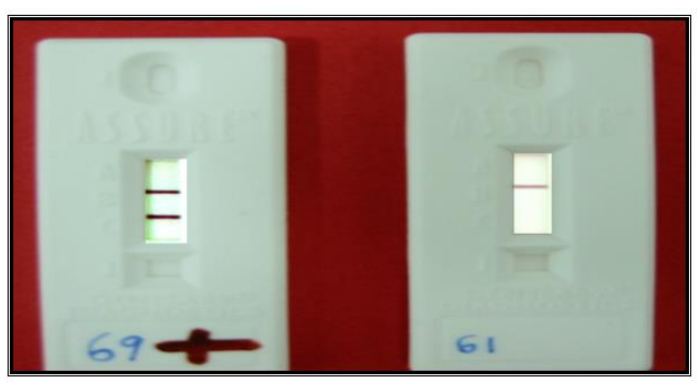

Gambar 1. Rapid Test Brugia (foto)

Penggunaan antigen rekombinan dikembangkan karena deteksi antibodi dengan menggunakan ekstrak filaria utuh/crude antigen memiliki reaksi silang terhadap antigen nematoda lain. Antigen rekombinan filaria (Bm14) yang dikembangkan oleh Lammie et al. (2004) telah diuji sensitifitas dan spesifitasnya. Studi dilakukan dengan membandingkan deteksi antibodi dengan menggunakan antigen rekombinan $\mathrm{Bm} 14$ dan $\mathrm{Bm} \mathrm{R} 1$ untuk mendeteksi IgG4 spesifik dengan metode ELISA (Gambar 2). Hasil studi dilaporkan bahwa penggunaan antigen Bm14 memiliki sensitivitas $91 \%$ untuk W. bancrofti, 96\% B. malayi sedangkan BmR1 memiliki sensitifitas $45 \%$ untuk W. bancrofti dan $100 \%$ untuk B. malayi. Antigen rekombinan $\mathrm{Bm} 14$ memiliki sensitifitas dan spesifitas lebih baik dibandingkan BmR1 untuk mendeteksi spesies Wuchereria dan Brugia (Lammie et al., 2004).

\section{MEKANISME TERBENTUKNYA IgG4 DARI INFEKSI FILARIASIS LIMFATIK}

Pada infeksi cacing, imunitas yang pertama mengenali adalah sel APC yaitu sel dendritik (DCs) atau makrofag yang akan aktif di jaringan yang terinfeksi, kemudian sel APC akan mengalami pematangan dan bermigrasi ke kelenjar limfe. Kemudian di kelenjar limfe, dimana DCs atau makrofag yang mature akan mempresentasikan antigen ke sel $T$ naïve untuk memulai imunitas adaptif (Gambar 3). Kemudian sel T naïve akan berpolarisasi dan 


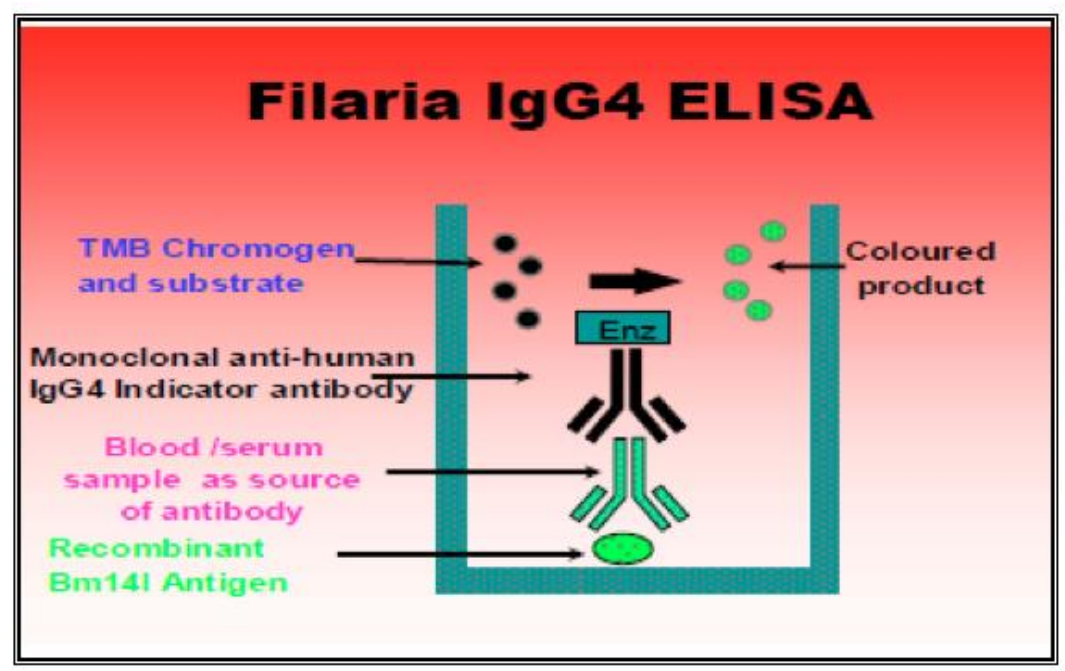

Gambar 2. Skema ELISA dengan menggunakan kit Bm14 coated antigen ${ }^{7}$

berkembang menjadi Th1, Th2, atau T reg, tergantung pada jenis antigen yang berikatan (Darwin, 2006 dan Karnen 2004).

Pada infeksi cacing / filaria sel T naive lebih dominan berkembang kearah Th2 yang secara dominan menghasilkan sitokin IL-4, IL-5, IL-9, IL-13 yang nantinya akan menginduksi proliferasi sel $B$, dan membentuk IgE dan IgG4 (Darwin, 2006 dan Karnen 2004).

Produksi IgG4 dan IgE saling berkaitan, dimana level IgE spesifik akan meningkat jika level antibody spesifik IgG4 menurun, dan sebaliknya. Respon IgG4 akan meningkat apabila dirangsang oleh antigen dan berhubungan langsung dengan kadar antigen. Sedangkan IgE akan mengalami down regulate apabila pemaparan antigen semakin tinggi (Terhell et al. 2002).

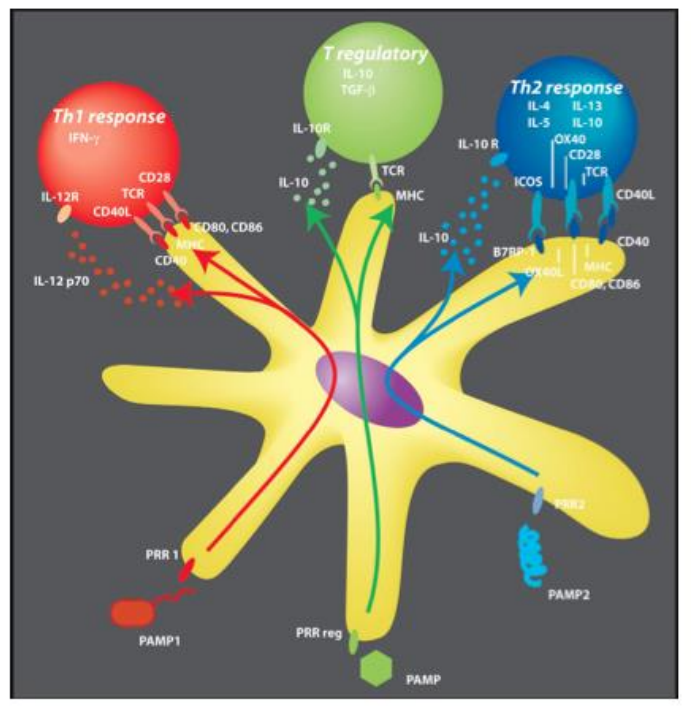

Gambar 3. Antigen Presenting Cell ${ }^{11}$

Pada filariasis limfatik terdapat tiga pola respon imun spesifik yang berhubungan dengan infeksi parasit ini:

1. Modifikasi $\mathrm{T}$ helper2 merupakan kelompok individu yang rentan terhadap infeksi. Kelompok ini memiliki respon Th2 yang lebih tinggi dibandingkan respon Th1 dan 


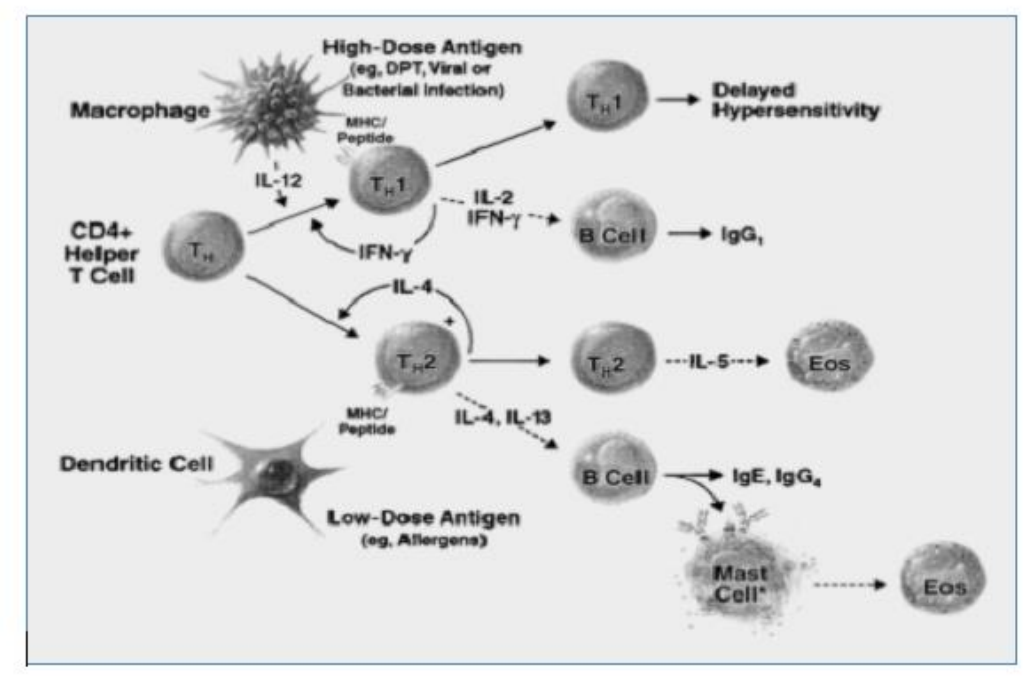

Gambar 4. Sel B memproduksi IgG4 dan IgE $\operatorname{Ig}^{12}$

mengekspresikan kadar IL-10 tinggi sebagai indikasi aktifitas $T$ reg yang kuat. Profil antibodi pada kelompok Th2 ini didominasi oleh antibodi IgG4 dengan IgE yang relatif rendah. Kelompok ini sering tidak menunjukkan gejala klinis namun menjadi hospes reservoir dalam penularan infeksi filariasis.

2. Pada kelompok kedua yaitu kelompok yang resisten terhadap infeksi ditandai oleh adanya respon Th1 dan Th2 yang dikontrol oleh aktifitas Treg. Keadaan respon Th1 dan Th2 yang seimbang cukup penting untuk membunuh adanya infeksi cacing. Profil antibodi dalam keadaan ini digambarkan dengan antibodi IgG4 yang rendah dan IgE yang meningkat.
3. Kelompok yang ketiga merupakan individu yang menunjukan respon Th1 yang tidak terkontrol. Th1 yang tinggi memicu respon inflamasi yang tidak terkontrol. Kelompok ini ditandai dengan kadar IgG4 yang rendah dan IgE yang lebih tinggi, pada filariasis respon imun yang kuat ini berhubungan dengan inflamasi limfatik yang memicu terjadinya keadaan patologi seperti elefantiasis akibat adanya kegagalan fungsi aliran limfe. Kasus ini diduga berhubungan dengan rendahnya aktifitas T reg (Terhell et al., 2002).

\section{IgG4 SEBAGAI MARKER SPESIFIK DIAGNOSIS FILARIASIS LIMFATIK}

$$
\text { Imunoglobulin G }
$$

merupakan antibodi yang paling banyak 


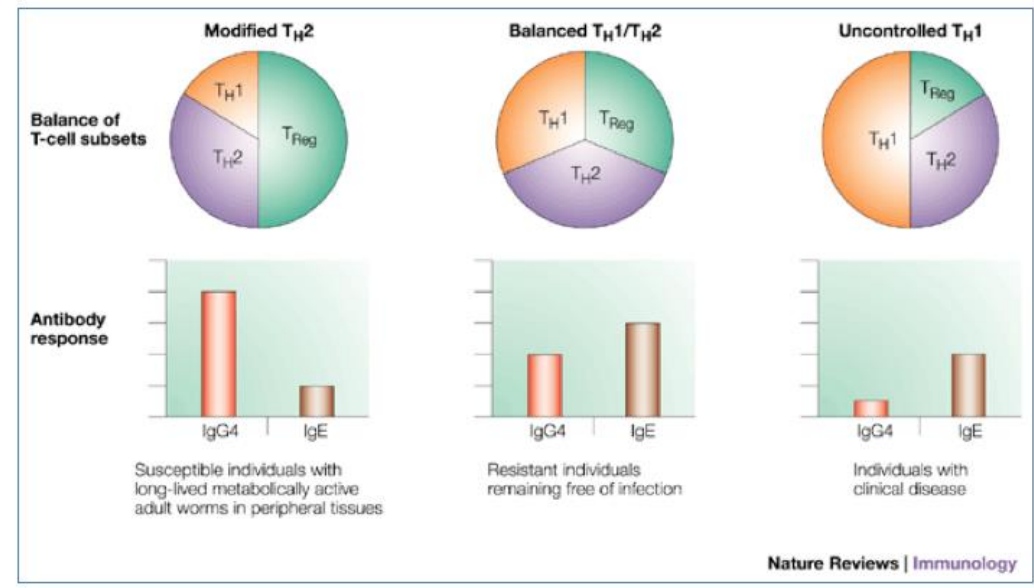

Gambar 5. Respon imunitas yang berbeda antara individu yang rentan, individu resisten, dan individu dengan gejala klinis ${ }^{13}$

terbentuk dalam cairan tubuh. Pada berikatan dengan antigen yang terdapat prinsipnya IgG dan IgM dibentuk di dalam bagian ekstraseluler yang dalam limfe, dan sumsum tulang, serta mengalami kerusakan serta jaringan beredar di dalam kelenjar getah bening yang terinfeksi (Karnen, 2004). IgG dan darah. sendiri pada manusia terdiri dari 4 subklas yaitu

Tabel 1. Hasil ELISA terhadap respon antibodi IgG dengan menggunakan antigen rekombinan BmR1 ${ }^{15}$

\begin{tabular}{llllll}
\hline Serum sampel & Jumlah & \multicolumn{4}{c}{ BmR1 positif (\%) } \\
\cline { 3 - 6 } & & IgG & IgG2 & IgG3 & IgG4 \\
\hline B. malayi, mf + & 10 & 100 & 0 & 0 & $\mathbf{1 0 0}$ \\
B. malayi, kronis & 14 & 100 & 0 & 0 & $\mathbf{1 0 0}$ \\
W. bancrofti, $\mathrm{mf}+$ & 6 & 100 & 0 & 0 & 24,24 \\
O. volvulus, $\mathrm{mf}+$ & 47 & 100 & 0 & 0 & 1,43 \\
Loa loa, $\mathrm{mf}+$ & 14 & 100 & 0 & 0 & 42,86 \\
STH & 10 & 100 & 0 & 0 & 0 \\
Kontrol & 10 & 100 & 0 & 0 & 0 \\
\hline
\end{tabular}

Namun antibodi IgG tersebut memiliki ukuran yang lebih kecil dibandingkan IgM sehingga lebih mudah untuk
IgG1，IgG2， IgG3，IgG4 yang berbeda dalam struktur, fungsi, dan peranannya terhadap respon kompleks antigen (Simonsen et al., 1998). Dalam kasus limfatik filariasis, respon antibodi IgG2 dan IgG3 meningkat lebih tinggi terjadi 
pada pada pasien elefantiasis

dibandingkan penderita mikrofilaremi (Terhell, 2002).

Peningkatan yang tinggi terjadi pada antibodi spesifik IgG4 anti filaria hingga mencapai $>95 \%$ dari total IgG pada infeksi aktif (pasien mikrofilaremi maupun pasien Tropical Pulmonary Eosinophilic sindrom) (Ottesen et al. 1985). Selain itu kadar IgG4 anti filaria juga menurun setelah diberikan pengobatan massal (Tisch et al, 2008). Keberadaan IgG4 yang mendominasi respon antibodi menjadikan IgG4 merupakan marker yang sensitif untuk filariasis.

\section{ANTIGEN REKOMBINAN Bm14}

Terdapat beberapa macam antigen rekombinan yang telah dipublikasikan untuk deteksi filariasis yaitu: BmR1, Bm5, BmHSP-70, BmIF, dan Bm14.
Masing - masing antigen rekombinan tersebut memiliki perbedaan sensitivitas dalam mendeteksi filariasis (Fisher et al., 2005).Klon terdekat pada Bm14 adalah WBSXP -1, yang diisolasikan dari pustaka cDNA berdasarkan pengenalan yang spesifik terhadap antibodi dari individu yang terinfeksi filaria. Panjang sekuen klon Bm14 adalah 1701 pb, terdiri dari 301 pb (Bm 14 S) dan 1400 pb (Bm $14 \mathrm{~L})$. dan sekuens target yang dipakai untuk mengekspresikan antigen rekombinan $\mathrm{Bm} 14$ adalah $\mathrm{Bm} 14 \mathrm{~S}$ (Chandrashekar et al., 1994).

Seleksi imun (immunoscreening) yang digunakan adalah pustaka cDNA cacing dewasa $B$. malayi di $\lambda$ gt11. Penyeleksian pustaka cDNA digunakan untuk mengindentifikasi klon spesifik filaria. Klon yang akan dipidipurifikasi adalah klon yang reaktif dengan serum filarial bankrofti dan tidak reaktif dengan serum nematoda yang lain, selanjutnya cDNA sudah dipilih (cDNA inserts) diamplifikasi dengan PCR

Tabel 2. Sensitifitas dan Spesifisitas dari IgG4 ELISA untuk antigen rekombinan Bm 14.

\begin{tabular}{lcc}
\hline Sumber serum & $\begin{array}{c}\text { Jumlah serum yang } \\
\text { diuji }\end{array}$ & $\begin{array}{c}\text { Jumlah serum yang } \\
\text { reaktif dengan Bm14 }\end{array}$ \\
\hline Filariasis Bankrofti (India) & 30 & 28 \\
Filariasis Bankrofti (Mesir) & 49 & 42 \\
Filariasis Brugia (India) & 32 & 27 \\
Ascaris lumbricoides & 10 & 0 \\
Schistocoma mansoni & 15 & 0 \\
Hymenoplepis nana & 4 & 0 \\
Enterobius vermikularis & 9 & 0 \\
\hline
\end{tabular}


Pemeriksaan menggunakan Bm14 dilaporkan memiliki sensitivitas yang sama (85 - 90\%) dalam mendeteksi IgG4 antifilaria dari individu yang terinfeksi oleh Brugia malayi, Brugia timori, maupun $W$. bancrofti. Oleh karena itu, penggunaan antigen rekombinan Bm 14 untuk deteksi IgG4 antifilaria dari ketiga spesies, lebih dapat diandalkan dibandingkan dengan antigen rekombinan lainnya (Lammie et al., 2004 dan Terhell, 2002).

\section{PENELITIAN DETEKSI ANTIBODI IgG4 SEBAGAI MARKER SPESIFIK DIAGNOSIS FILARIASIS LIMFATIK DENGAN MENGGUNAKAN ANTIGEN REKOMBINAN Bm14.}

Penelitian

imunodiagnostik

tentang antigen $\mathrm{Bm} \quad 14$ dalam mendeteksi IgG4 anti filaria, pertama kali dilakukan dilakukan pada tahun 1994 oleh Chandrashekar et al. Pada study ini dicoba, mengkarakterisasi antigen rekombinan $\mathrm{Bm} 14$ spesific filaria yang berpotensi menjadi imunodiagnostik pada filariasis.
Sampel diambil dari pasien dengan filariasis brugia dari India, dan filariasis bancrofti dari India dan Mesir. Kemudian pengukuran dilakukan terhadap antibodi IgG4 antifilaria dengan metode ELISA.

Serum kontrol didapatkan dari pasien yang terinfeksi Schistosoma mansoni, Ascaris lumbricoides, Hymenoplepis nana, dan Enterobius vermikularis. Hasil penelitian yang didapatkan adalah $90 \%$ dari serum pasien filariasis di India dan Mesir reaktif dengan antigen rekombinan $\mathrm{Bm}$ 14. Sehingga Bm14 dapat berguna untuk alat diagnostik dalam mendeteksi infeksi filaria. Sedangkan di Indonesia sendiri, penelitian deteksi antibodi IgG4 merupakan marker yang sensitif untunk filariasis telah dilakukan di Sulawesi Selatan. Penelitian ini menginvestigasi prevalensi infeksi B. malayi di daerah endemik, ditentukan dengan level IgG4 dengan standar ELISA.

Tabel 3. Sensitivitas dan Spesifisitas Pemeriksaan Antibodi.

\begin{tabular}{lcccc}
\hline \multicolumn{1}{c}{ Infeksi } & $\begin{array}{c}\text { Bm14 } \\
\text { ELISA te } \\
\text { positif (\%) }\end{array}$ & $\begin{array}{c}\text { WbSXP } \\
\text { cassette test } \\
\text { positif (\%) }\end{array}$ & $\begin{array}{c}\text { BmR1 ELISA } \\
\text { tes positif (\%) }\end{array}$ & $\begin{array}{c}\text { BmR1dipstick } \\
\text { tes positif (\%) }\end{array}$ \\
\hline $\boldsymbol{W}$ bancrofti & $\mathbf{9 1 \%}$ & $\mathbf{9 1 \%}$ & $\mathbf{4 5 \%}$ & $\mathbf{5 6 . 7 \%}$ \\
B. malayi & $\mathbf{9 6 \%}$ & $\mathbf{3 9 \%}$ & $\mathbf{1 0 0 \%}$ & $\mathbf{1 0 0 \%}$ \\
O. volvulus & $69 \%$ & $60 \%$ & 0 & $5 \%$ \\
Loa-loa & $78 \%$ & $43 \%$ & 0 & 0 \\
$\begin{array}{l}\text { Nematoda lain } \\
(\text { A. lumbricoides })\end{array}$ & 0 & 0 & 0 & 0 \\
\hline
\end{tabular}


Penelitian tentang antigen rekombinan $\mathrm{Bm} 14$ telah dilakukan oleh Lammie PJ et al (2004). Penelitian ini mendemonstrasikan sensitivitas dari pemeriksaan antibodi oleh antigen rekombinan yang sedang dikembangkan, yaitu Bm14, WbSXP dan BmR1. Dilakukan 3 pemeriksaan yang berbeda yaitu ELISA, dipstik, dan cassette.

Hasil penelitian dilaporkan bahwa antigen rekombinan $\mathrm{Bm} 14$ lebih sensitif dan spesifik dalam mendeteksi filariasis bankrofti dan filariasis Brugia, dibandungkan dengan antigen rekombinan yang lain. Penelitian dengan marker IgG4 dengan antigen rekombinan Bm14, kembali diterapkan oleh Daniel JT et al pada tahun 2008.
Penelitian ini membandingkan prevalensi mikrofilaria, keberadaan antigen dan antibodi pada komunitas filarial yang telah diberikan pengobatan 5 tahun dengan dosis tunggal DEC dikombinasikan dengan ivermectin di Papua New Guinea. Pengukuran dilakukan sebelum pengobatan, 4 tahun sesudah pengobatan, dan 5 tahun sesudah pengobatan.

Hasil yang dilaporkan adalah terjadi penurunan antibodi yang berkelanjutan pada treatment 4 tahun, dan menurun lagi setelah 5 tahun pengobatan. Hal ini menunjukan bahwa antibodi IgG4 anti-filaria tinggi pada infeksi aktif dan mengalami penurunan setelah pengobatan massal.

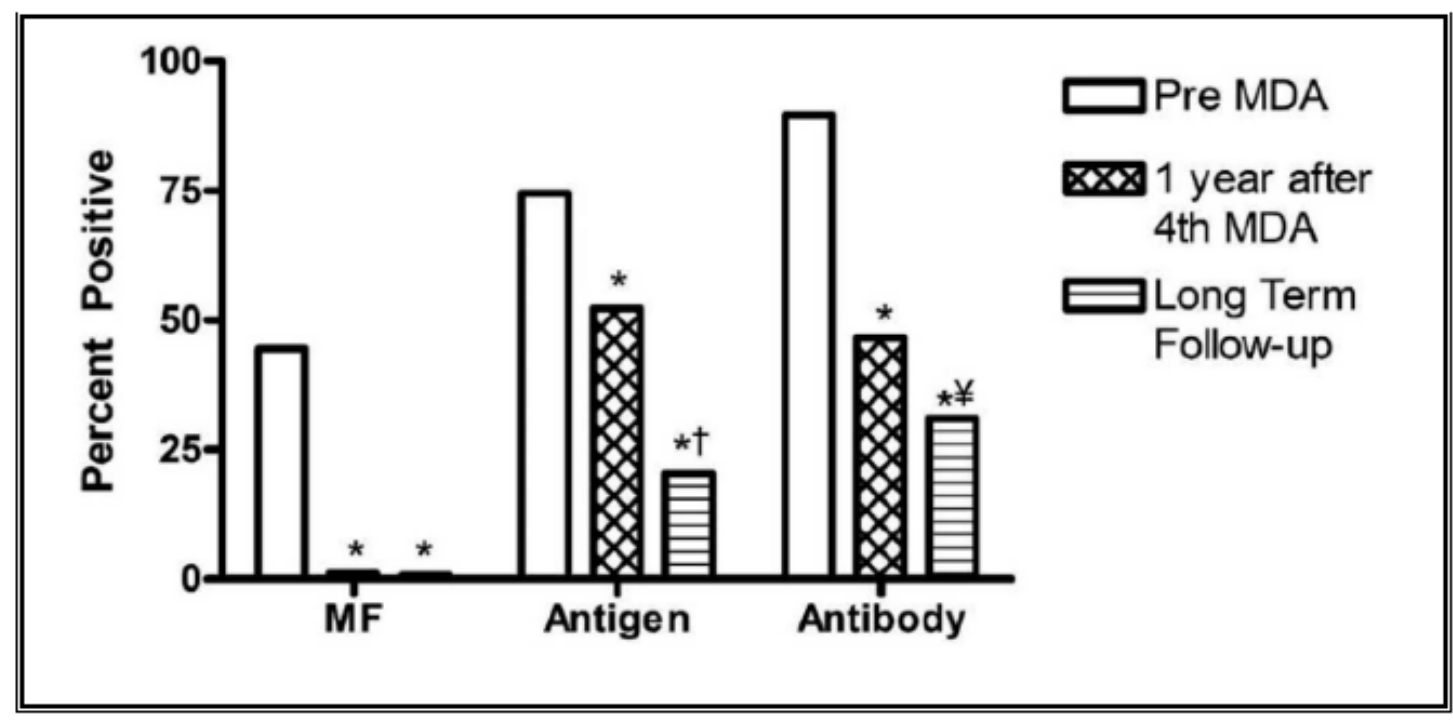

Gambar 6. Grafik perbandingan penurunan mikrofilaria, antigen, dan antibodi dengan pengobatan massal 5 tahun (dosis tunggal DEC dikombinasikan dengan ivermectin). 


\section{KESIMPULAN}

Deteksi antibodi IgG4 anti-filaria dengan menggunakan antigen rekombinan $\mathrm{Bm} 14$ merupakan cara diagnosis yang tepat untuk filarisis. Hal ini didasarkan pada pengukuran level antibodi IgG4 yang meningkat secara signifikan pada infeksi aktif dan penurunan level antibodi IgG4 tersebut setelah pengobatan massal. Selain ini IgG4 antifilaria juga dapat terdeteksi pada individu yang negatif mikrofilaria maupun antigen. Bm 14 merupakan rekombinan antigen yang memiliki sensitifitas dan spesifisitas yang baik dalam mendeteksi filariasis bankrofti dan filariasis brugia, sehingga dapat lebih efektif dan diandalkan di Indonesia.

\section{DAFTAR PUSTAKA}

Chandrashekar R, Curtis KC, Ramzy RM, Liftis F, Li B, et al. Molecular cloning of Brugia malayi antigen for diagnosis lymphatic filariasis. Molecular and Biochemical Parasitology.1994;261-71.

Darwin E. Imunologi dan Infeksi. Andalas University Press. 2006:11317.

Fischer $P_{\text {. }}$, et al. Detection of filariaespecific IgG4 antibodies and filarial DNA, for the screening of blood spots for Brugia timori. Annals of tropical Med. \& Par. 2005;99(1): 53-60.

Haarbrink M, Terhell A, Abadi K, Bers SV, Asri $M$, et al. IgG4 antibodi assay in detection of Filariasis. The Lancet.1995; 346: 853-54.
Karnen GB. Imunologi Dasar, edisi ke 6. Balai Penerbit FKUI. 2004; i-xviii:1327.

Kresno SB. Respon imun pada infeksi. Dalam: Imunologi: Diagnosis dan Produser Laboratorium.Edisi ke-4. Jakarta: Balai Penerbit FKUI 2007; 161-86

Kumari S, Lillibrigde $C D$, Bakeer $M$, Lowwrie RC, Jayaraman $\mathrm{K}$, et al. Brugia malayi: the diagnostic potential o rekombinan excretory/secretory antigen. Experimental parasitology. 1994;409-505.

Lammie PJ, et al. Recombinant antigen-based antibodi assays for the diagnosis and surveillance of lymphatic filariasis- a multicenter trial. Filarial journal. 2004; 3(9): 1-5.

Ottesen EA, et al. Prominance of IgG4 in the IgG antibodi response to human filariasis. J. Immunol. 1985;134(4): 2707-2712

Ottesen EA, Editorial: The global programme to eliminate lymphatic filariasis. Tropical Medicine and International Health. 2000: 5; 591 94.

Rajasekariah GH, Dogcio D, Smiththyman AM. Development of prototype ELISA and RDT sentinel assay for monitoring exposure to lymphatic filarial infection. Cellabs.

Scott AL. Lymphatic-dwelling filariae. In: Nutman TB, Pasvol G, Hoffman SL. Editor. Lymphatic Filariasis. Volume 1. London: Imperial College Press; 2000.p.

Simonsen PE and Meyrowitsch DW. Bancroftian filariasis in Tanzania: Specific antibodi responses in relation to long term observations on microfilaremia. Am. J.Trop. Med. Hyg. 1998;59(5):667-672.

Terhell A, Epidemiological facets of lymphatic filariasis as revealed by use 
of antifilarial IgG4. Disertasi. 2002:1049.

Terhel A, Stolk W, Haarbrink M, Mangali A, Oortmarssen GV et al. Regulation of antifilarial IgE by infection pressure. In: Terhell A, Epidemiological facets of lymphatic filariasis as revealed by use of antifilarial IgG4. Disertasi. 2002:108 9.

Tisch DJ, Bockarie MJ, Dimber Z, Kiniboro B, Tarongka N, et al. Mass drug administration trial to eliminate lymphatic filariasis in Papua New Guinea: changes in microfilaremia, filarial antigen, and $\mathrm{Bm} 14$ antibodi after cessation. Am J Trop Med Hyg. 2008, 78(2):289-293.

Weil GJ, Ramzy RM, El Setouhy M, Kandil AM, Ahmed ES, Farris R: A longitudinal study of bancroftian filariasis in the Nile Delta of Egypt: baseline data and one-year follow up. Am J Trop Med Hyg 1999, 61:53-58.

Wibowo, H. Imunology Helminth. Disampaikan pada Kuliah Imunologi Dasar Jakarta, 7 September, 2008. 